\title{
Analysis of influencing factors on using rental bikes at shopping tourism sites in Surakarta
}

\author{
Erlin Setyowati ${ }^{1,}$, Dewi Handayani ${ }^{2}$, and Syafi ${ }^{2}{ }^{2}$ \\ ${ }^{1}$ Student of Master Program of Civil Engineering, Sebelas Maret University, Surakarta, Indonesia \\ ${ }^{2}$ Lecturer of Master Program of Civil Engineering, Sebelas Maret University, Surakarta, Indonesia
}

\begin{abstract}
Surakarta as a tourism city has launched green transportation as a program in the government policy. Bikes as a supporting mode of green transportation has not gotten much attention from users, including tourism sites. Therefore, the aim of this study is to obtain the factors which influence the use of tourism bikes in Surakarta in the form of rental bikes. The location of the study was at several shopping tourism sites in Surakarta, namely Pasar Gede, Pusat Grosir Solo, Beteng Trade Center, and Pasar Klewer. The data was collected using a questionnaire with an interview method to the respondents of the visitors of the shopping sites and analyzed with the PCA (Principal Component Analysis) method. The result of the research showed that the weather condition, air pollution, bike track topography, and distance were the main factors which influenced people to use rental bikes in tourism sites of Surakarta.
\end{abstract}

\section{Introduction}

Increasing the number of motor vehicles makes many impacts, such as traffic jam, high air pollution, environmental pollution, fuel waste of vehicles, etc. One of the government's efforts to overcome this problem, especially in Surakarta City as a tourist city, is to design a system called green transportation, which is a transportation system that aims to reduce greenhouse gas emissions, air pollution, noise, and reduce poverty and support economic growth [1]. In this case, Pasar Gede, a shopping place in Surakarta, has characteristics that present a sense of place from the symbiosis of relationships between physical places, actors and livelihoods [2].

One of the alternatives to support the green transportation program is by using bicycles. Using bicycles is a priority strategy towards environmentally friendly transportation [3]. Bicycles do not use fuel and do not generate carbon emissions [4], but most road users tend to choose to use motor vehicles that are reach their destination faster regardless of the impact that will be generated. The impact is global warming, non-renewable energy / resources, inorganic respiratory and organic respiratory, which is the largest contributor of the total impact on the environment [5]. A solution to overcome these effects is bicycle rental.

\footnotetext{
* Corresponding author: erlinsetyowaty@gmail.com
} 
The bicycle rental program is the most common method of providing bicycles for tourists in recreational areas [6]. In this case, many things need to be considered in supporting the program. One way to support the program is by knowing the reason that people use bicycle rental. The influencing factors consist of the socioeconomic characteristics of the community, the habits of bicycle users and driving habits, as well as the location of bike stations or bicycle shelters [7]. The use of rental bikes is also influenced by household income, location of bicycle rental stations, and user perceptions about bicycle distribution [8]. In addition, factors affecting the use of bicycles are demographic characteristics, bicycle infrastructure facilities, land use characteristics and imbalances of bike disposal operational systems that are affected by the peak usage times of bike land use characteristics, and bicycle infrastructure facilities [9].

Therefore, this study aims to determine the most influential factors in the use of rental bikes at shopping sites in Surakarta City, among others, in Pasar Gede, Solo Wholesale Center, Beteng Trade Center, and Klewer Market. These very influential factors are what need attention to lease bike planning for the realization of environmentally friendly transportation.

\section{Research method}

\subsection{Bicycle rent}

Bicycle rental is a mode of transportation for short distance travel, for example from residence or stay, to a shopping location or bus stop and train station. A special station is provided to pick up the bike and return it at another station closest to the user's destination [10].

Factors that can influence the selection of modes that consists of the first four factors that characterize road users consist of vehicle ownership, ownership of driving license, household structure, and income. The second factor is the characteristic of movement which consists of the purpose of movement, the time of movement, and the distance of movement. The third factor is the characteristics of transportation mode that consists of travel time, transportation cost, availability of space and fee parking, security, comfort, and reliability. The fourth factor is the characteristics of a city or zone consisting of distance from the city center and population density [11].

\subsection{Variables factor of using rental bicycles}

Factors of the usage of rental bicycles consist of social economic characteristics, bicycle user habits, location of bike stations or shelter, social economic characteristics, bicycle ownership, BIXI (bike sharing) membership, fear of loss of bike, unbearable bike maintenance, and shelter location [7]. The use of bicycle rental is also influenced by travel mode, frequent use of bike sharing, station or shelter location, eco-friendly, bike sharing publications, travel time ( $<30$ minutes), gender, easiness of route, and time spent traveling [8]. Other factors include weather, air pollution conditions, bike trail topography, mileage, demographic line capacity, bicycle infrastructure, land use characteristics, peak use times, land use characteristics, and bicycle infrastructure facilities [9]. The next factor is bike lanes, signs for bicycles [12], maps or routes for cyclists, and bike operators. And then the next factor is the cost of renting a bike, the ease of access using an application for bike rental and ease of understanding of the instructions on the application [13]. 


\subsection{Method}

The data in this study is collected by an interview using questionnaires in a shopping tour in Surakarta City. The data analysis technique used is factor analysis, which is a multivariate statistic analysis technique used to reduce and conclude the variables into factors.

The factor analysis method uses the principal component analysis of PCA (Principal Component Analysis), which is a statistical technique to change most of the original variables that correlate one with another into a set of new variables smaller and independent (no longer correlated). So, the main component analysis is useful for reducing data, making it easier to interpret the data [14].

This study is to research the aspect where there are environmental conditions consisting of weather, air pollution conditions, bike topography, mileage, bike lane capacity, separator with other modes [9]. Aspects of support facilities consists of bicycle paths, signs for bicycles [12], maps or routes for cyclists, and bike operators [8]. Aspects of service levels consists of bicycle rental fees, ease of access using applications for rent bikes and ease of understanding instructions on applications [13].

\section{Equations and mathematics}

\subsection{Validity and reliability test}

In this study validity is calculated using $\mathrm{df}$ (degree of freedom) with the formula $\mathrm{df}=\mathrm{n}-2$, and with alpha 5\%. If the $r$ count is much larger than the $r$ table and the value of $r$ is accepted, then the question item is to be valid [15]. This data obtained the value of $r$ table, which is 0,1966 , and the value of $r$ count is larger than $r$ table so the question item is valid and the alpha value of 0.679 is more than 0,6 , which means it has sufficient reliability.

\subsection{Factors analysis}

After ensuring that the data used is eligible, then PCA analysis can be continued. PCA analysis begins by calculating the correlation value between variables. In this analysis, the correlation of each variable is formed in a correlation matrix. The formation of a new variable is based on more than one eigenvalue. The results of the calculation of eigenvalues and variance can be seen below.

From Table 1, it can be seen that there are four main factors that represent eigenvalue value that has a value of more than 1 . These four factors have eigenvalue sequential. The first prequel component has an eigenvalue of 3.056 (variance of 23,509\%). The second predictor component has an eigenvalue of 2.727 (variance of 20,973\%). The principal third component has an eigenvalue of 2,003 (variance of $15,411 \%$ ). The fourth principal component has an eigenvalue of 1.118 (variance of $8,602 \%$ ). These fourth principal components are able to explain the data diversity of $68,495 \%$ seen from $\%$ total variance. To determine the new five variables that are very influential on using bicycles then rotation matrix factor. 
Table 1. Eigen value of main component analysis result (PCA).

\begin{tabular}{|c|c|c|c|}
\hline \multirow{2}{*}{ Component } & \multicolumn{3}{|c|}{ Initial Eigenvalues } \\
\cline { 2 - 4 } & Total & $\begin{array}{c}\text { \% of } \\
\text { Variance }\end{array}$ & $\begin{array}{c}\text { Cumulative } \\
\text { \% }\end{array}$ \\
\hline Weather & 3.056 & 23.509 & 23.509 \\
\hline air pollution & 2.727 & 20.973 & 44.483 \\
\hline topography line & 2.003 & 15.411 & 59.893 \\
\hline Mileage & 1.118 & 8.602 & 68.495 \\
\hline capacity line & 0.989 & 7.611 & 76.106 \\
\hline barrier modal & 0.935 & 7.191 & 83.297 \\
\hline availability bicycle line & 0.659 & 5.066 & 88.364 \\
\hline bike signs & 0.450 & 3.464 & 91.828 \\
\hline bicycle map & 0.420 & 3.234 & 95.062 \\
\hline bicycle operator & 0.276 & 2.125 & 97.187 \\
\hline rental fee & 0.206 & 1.585 & 98.772 \\
\hline easy of application access & 0.123 & 0.945 & 99.716 \\
\hline easy of application instruction & 0.037 & 0.284 & 100.00 \\
\hline
\end{tabular}

(source: Setyowati ${ }^{1}$.E. et al. 2018)

Table 2. Rotated component matrix.

\begin{tabular}{|c|c|c|c|c|}
\hline \multirow{2}{*}{ Variable } & \multicolumn{4}{|c|}{ New Component } \\
\cline { 2 - 5 } & $\mathbf{1}$ & $\mathbf{2}$ & $\mathbf{3}$ & $\mathbf{4}$ \\
\hline weather & 0.821 & 0.021 & 0.059 & 0.029 \\
\hline air pollution & 0.818 & -0.022 & -0.044 & -0.070 \\
\hline topography line & 0.779 & -0.022 & -0.038 & -0.075 \\
\hline mileage & 0.859 & -0.022 & -0.002 & -0.014 \\
\hline capacity line & 0.427 & 0.139 & 0.634 & 0.214 \\
\hline barrier modal & 0.053 & 0.068 & 0.817 & 0.278 \\
\hline availability bicycle line & -0.011 & -0.088 & 0.130 & 0.826 \\
\hline bike signs & -0.087 & 0.110 & 0.156 & 0.834 \\
\hline bicycle map & -0.127 & -0.097 & 0.637 & 0.046 \\
\hline bicycle operator & -0.062 & 0.151 & 0.746 & -0.005 \\
\hline rental fee & 0.265 & 0.577 & 0.260 & -0.088 \\
\hline easy of application access & -0.109 & 0.957 & 0.001 & 0.053 \\
\hline easy of application & -0.114 & 0.953 & -0.02 & 0.043 \\
\hline instruction & & & &
\end{tabular}

(source: Setyowati ${ }^{1}$.E. et al. 2018)

In Table 2. the correlation relationship between the original variable and the new variable (principal component) formed with PCA is called the loading value. The value of loading taken above is 0.5 which is considered to be able to explain the variables that affect people using the bike. Variables whose value is below 0.5 are considered less influential in the use of bicycles. The newly formed variable has represented 13 variables in the original data. Then Table 3 will show in detail the variables that affect the use of bicycles. 
Table 3. Summary of main component analysis (PCA).

\begin{tabular}{|c|c|c|c|c|}
\hline Factor & Eigenvalue & $\begin{array}{c}\text { Varian } \\
\text { value }(\%)\end{array}$ & Variable & $\begin{array}{l}\text { loading } \\
\text { factor }\end{array}$ \\
\hline \multirow{4}{*}{1} & \multirow{4}{*}{3.056} & \multirow{4}{*}{23.509} & weather & 0.821 \\
\hline & & & air pollution & 0.818 \\
\hline & & & topography line & 0.779 \\
\hline & & & mileage & 0.859 \\
\hline \multirow{3}{*}{2} & \multirow{3}{*}{2.727} & \multirow{3}{*}{20.973} & rental fee & 0.577 \\
\hline & & & easy of application access & 0.957 \\
\hline & & & easy of application instruction & 0.953 \\
\hline \multirow{4}{*}{3} & \multirow{4}{*}{2.003} & \multirow{4}{*}{15.411} & capacity line & 0.634 \\
\hline & & & barrier modal & 0.817 \\
\hline & & & bicycle map & 0.637 \\
\hline & & & bicycle operator & 0.746 \\
\hline \multirow{2}{*}{4} & \multirow{2}{*}{1.118} & \multirow{2}{*}{8.602} & availability bicycle line & 0.826 \\
\hline & & & bike signs & 0.834 \\
\hline
\end{tabular}

(source: Setyowati ${ }^{1}$.E. et al. 2018)

In Table 3. the first component principal has a variance percentage value of $23.509 \%$. At the value of the loading variable forminged the first component principal is the weather 0.821 ; air pollution 0.818 ; topography line $0.779 \%$ : mileage $0.859 \%$. The second component principal has a value of variance percentage of $20.973 \%$. At the value of the loading variable forming principal second component that are rental fee 0.577 ; ease of application access 0.957; ease of application instruction 0.953. Principal third component has the value of variance percentage as much as $15.411 \%$. At the loading value variable forming principal third component that are capacity line 0.634 ; barrier modal 0.817 ; bicycle map 0.637; bicycle operator 0.746. Principal fourth component has a value of variance percentage as much as $8.602 \%$. At the loading value of the forming variable principal component of the fourth are availability bicycle line 0.826 ; bike signs 0.834 .

\section{Conclusions}

The results of the data obtained are four new variables that determine the factors that affect the influence of tourists using bicycle rental in shopping in Surakarta. The four new variables formed will be able to explain from the total variant of $68.495 \%$. The four new variables include weather. air pollution. topography of bike lanes. and mileage. From the previous study it is stated that the result of factor analysis found 6 main factors namely the factors of pleasure. physical and environment. safety. convenience. personal barriers. and necessity. While the most important results of the cycling facility sequence are the lane. bicycle route. parking. bicycle parking in the terminal or station. rules that support cycling. bike repair. bike shop. bicycle rental and public bike. bike sharing. bus with shelf for bicycles. bicycles for equipment at terminals or stations. and bathing places for cyclists at work [16].

It is expected that further research will be conducted to improve the arrangement of better transportation system. convenient. safe. and environmentally friendly by using bicycles. 


\section{References}

1. D Bogardt and P Schaltenberg. "Transport in a Green Economi". http://www.gtz.de/transport (2011)

2. Aliyah. I., Setioko. B., \& Pradoto. W. Fleksibilitas Ruang dalam Transformasi Budaya di Kawasan Pasar Tradisional Kota Surakarta (Obyek Studi: Pasar Gede Kota Surakarta). (2015)

3. Onogawa. K. Environment Sustainable Transport for Asian Cities. japan: UNCRD. Minister of the Environment Goverment of Japan. (2007b).

4. Munggarani. Sepeda Sebagai Alat Transportasi Ramah Lingkungan. Jurnal Managemen Bisnis Transportasi Dan Logistik Vol. 3 No. 01, 9-18. (2018).

5. .Harjanto. T. R. Life Cycle Assessment pilihan Penggunaan Alat Transportasi Bagisiswa Sma Di Cilacap Dalam Kerangka Penerapan Mekanisme Pembangunan Bersih. Ratih. 2(1), 13. (2018).

6. Yan. S., Lin. J. R., Chen. Y. C., \& Xie. F. R. Rental bike location and allocation under stochastic demands. Computers \& Industrial Engineering. 107, 1-11. (2017).

7. Bachand-Marleau. J., Lee. B., \& El-Geneidy. A. Better understanding of factors influencing likelihood of using shared bicycle systems and frequency of use. Transportation Research Record: Journal of the Transportation Research Board. (2314), 66-71. (2012).

8. Guo. Yanyong. et al. "Identifying the factors affecting bike-sharing usage and degree of satisfaction in Ningbo. China." (2017)

9. Faghih-Imani. A., Hampshire. R., Marla. L., \& Eluru. N. An empirical analysis of bike sharing usage and rebalancing: Evidence from Barcelona and Seville. Transportation Research Part A: Policy and Practice. 97, 177-191. (2013).

10. Boseh bike. Bandung. Indonesia. (2016).

11. Tamin. O.Z. Perencanaan dan Pemodelan Transportasi. Penerbit ITB. (1997)

12. Brinkmann. J., Ulmer. M. W., \& Mattfeld. D. C. Inventory routing for bike sharing systems. Transportation Research Procedia. 19, 316-327. (2016).

13. Zander. Alexis. et al. "Active travel to work in NSW: trends over time and the effect of social advantage." Health Promotion Journal of Australia 25.3, 167-173. (2014)

14. Johnson. R. A. Wichern., DW. Applied multivariate statistical analysis. (1982).

15. Chariri. A., \& Ghozali. I. Teori Akuntansi Edisi 1. Semarang: Badan Penerbit UNDIP. (2001).

16. Mawening. i. T., Haryadi. B., \& Setiadji. B. H. Strategi pengembangan fasilitas untuk meningkatkan motivasi bersepeda masyarakat kota surakarta (doctoral dissertation. magister teknik sipil). (2014). 